\title{
Level Aktivitas Fisik dan Kualitas Hidup Warga Lanjut Usia
}

\section{Physical Activity Level and Quality of Life of The Elderly}

\author{
Syamsumin Kurnia Dewi \\ Akademi Fisioterapi "YAB" Yogyakarta \\ (drdewik98@gmail.com)
}

\begin{abstract}
ABSTRAK
Penelitian terdahulu menunjukkan bahwa partisipasi aktif dalam kegiatan olahraga merupakan faktor utama yang berhubungan dengan kualitas hidup peserta posyandu lanjut usia (lansia). Oleh karena itu, penelitian ini dilakukan untuk mengetahui hubungan level aktivitas fisik dan kualitas hidup lansia di Kecamatan Bambanglipuro, Bantul. Suatu studi cross-sectional dilaksanakan selama JuniSeptember 2017. Sampel adalah 123 subjek lansia di Bambanglipuro yang terpilih melalui teknik consecutive sampling. Level aktivitas fisik diukur dengan IPAQ-short form. Kualitas hidup diukur dengan kuesioner SF-36 dan dinyatakan dalam 2 skala: kualitas kesehatan fisik dan kualitas kesehatan mental. Data dianalisis dengan uji chi-square dan multiple logistic regression. Hasil menunjukkan mayoritas lansia memiliki kualitas kesehatan fisik dan kualitas kesehatan mental yang baik $(69,1 \% ; 76,4 \%)$. Analisis multivariat menunjukkan bahwa level aktivitas fisik yang tinggi dan tidak adanya hipertensi berhubungan dengan kualitas kesehatan fisik yang baik $(\mathrm{aPR}=9,38 ; 95 \% \mathrm{CI}=1,81-48,45$ vs aPR $=5,12$; $95 \% \mathrm{CI}=1,55-16,93)$ dan kualitas kesehatan mental yang baik $(\mathrm{aPR}=11,87 ; 95 \% \mathrm{CI}=2,50-56,33$ vs $\mathrm{aPR}=$ 4,$39 ; 95 \% \mathrm{CI}=1,16-16,70$ ). Terbukti bahwa level aktivitas fisik yang tinggi dan tidak adanya status hipertensi berhubungan dengan kualitas hidup yang baik dari lansia.
\end{abstract}

Kata kunci : Level aktivitas fisik, kualitas hidup, lanjut usia

\section{ABSTRACT}

A previous study showed active participation in physical exercise program was the major factor related to better quality of life in Community Elderly Care Services (CECS) participants. This study, therefore, undertaken to know the relationship between physical activity level and quality of life of the elderly at Bambanglipuro subdistrict, Bantul. A cross-sectional study was conducted from JuneSeptember 2017. Samples were 123 elderly subjects selected with consecutive sampling technique. Physical activity level was measured with IPAQ-short form. Quality of life was measured with The SF36 Health Survey, including the Physical Component Summary (PCS) and Mental Component Summary (MCS). Data then were analyzed using chi-square test and Multiple Logistic Regression. Results showed most of the elderly have better PCS and MCS $(69,1 \% ; 76,4 \%)$. Multivariate analysis showed high physical activity level and the absence of hypertension was related to better PCS $(a P R=9.38$; $95 \% C I=1.81$ 48.45 vs $a P R=5.12 ; 95 \% C I=1.55-16.93)$ and better $M C S(a P R=11.87 ; 95 \% C I=2.50-56.33$ vs $a P R=$ 4.39; $95 \% C I=1.16-16.70)$. High physical activity level and the absence of hypertension were related to better quality of life of the elderly.

Keywords : Physical activity level, quality of life, the elderly

Copyright (C) 2018 Universitas Hasanuddin. This is an open access article under the CC BY-NC-SA license (https://creativecommons.org/licenses/by-nc-sa/4.0/).

DOI : http://dx.doi.org/10.30597/mkmi.v14i3.4604 


\section{PENDAHULUAN}

Kualitas hidup saat ini merupakan sebuah konsep penting yang dijadikan sebagai salah satu kriteria untuk mengevaluasi intervensi pelayanan kesehatan. ${ }^{1}$ Menurut World Health Organization (WHO) kualitas hidup adalah persepsi individual tentang kesehatan fisik, status psikologis, derajat kemandirian, hubungan sosial, keyakinan pribadi, dan hubungan yang istimewa dari seseorang di masyarakat. ${ }^{2}$ Berbagai metode pengukuran kualitas hidup telah dikembangkan saat ini, diantaranya adalah Medical Outcomes Study Short Form36 atau yang dikenal dengan kuesioner SF-36. Dengan metode ini, kualitas hidup dinyatakan dalam 2 skala yaitu: kualitas kesehatan fisik/Physical Component Summary (PCS) dan kualitas kesehatan mental/Mental Component Summary (MCS). ${ }^{3}$

Konsep ukuran kualitas hidup dinilai lebih komprehensif sehingga kajian tentang kualitas hidup semakin berkembang, termasuk pada warga lanjut usia (lansia). Undang-Undang Republik Indonesia Nomor 36 Tahun 2009 tentang Kesehatan pada Pasal 183 Ayat 1 menyatakan bahwa: "Upaya pemeliharaan kesehatan bagi lansia harus ditujukan untuk menjaga agar tetap hidup sehat dan produktif secara sosial maupun ekonomis sesuai dengan martabat kemanusiaan." ${ }^{\prime 4} \mathrm{Hal}$ ini mencerminkan bahwa upaya pelayanan kesehatan lansia di Indonesia saat ini juga ditujukan kepada peningkatan kualitas hidup lansia.

Berdasarkan telaah pustaka yang ada, kualitas hidup lansia dipengaruhi oleh faktor-faktor sebagai berikut : (1) Level aktivitas fisik. ${ }^{5-8}$ (2) Faktor sosiodemografi, yang meliputi: jenis kelamin, usia, dan status sosial ekonomi., ${ }^{1,-11}$ (3) Faktor permasalahan kesehatan yang disandang, yaitu: hipertensi, arthritis, penyakit kronis, dan obesitas. ${ }^{6,8,9,11,12}$ (4) Partisipasi aktif dalam: program edukasional, perawatan lansia, serta program keagamaan. ${ }^{13-16} \mathrm{Di}$ antara faktor-faktor tersebut, WHO menekankan pentingnya aktivitas fisik dalam meningkatkan kualitas hidup lansia. Hal ini dituangkan melalui "Global Recommendations on Physical Activity for Health", yang diantaranya berisi rekomendasi aktivitas fisik pada lansia. ${ }^{17}$

Sebuah systematic review terhadap artikel penelitian tentang aktivitas fisik pada lansia di seluruh dunia pada tahun 2000-2012 menunjukkan bahwa aktivitas fisik secara konsisten ber- hubungan dengan kapasitas fungsional, kualitas hidup secara menyeluruh, otonomi, aktivitas masa lampau, saat ini, dan masa yang akan datang, kematian, keintiman hubungan, kesehatan mental, vitalitas, dan kondisi psikologis. ${ }^{18}$ Subjek yang memiliki level aktivitas fisik yang tinggi terbukti berhubungan dengan kesehatan dan kualitas hidup yang lebih baik, skor kesepian yang lebih rendah, dan lebih aktif berpartisipasi dalam kegiatan sosial, termasuk sebagai relawan. ${ }^{7}$ Aktivitas fisik yang lebih tinggi juga berhubungan dengan waktu yang dihabiskan untuk duduk yang lebih rendah, kekuatan cengkeraman yang lebih tinggi, rendahnya disabilitas dalam aktivitas sehari-hari, Indeks Massa Tubuh (IMT) yang lebih rendah, kecemasan yang lebih rendah, dan kemampuan kognitif yang lebih tinggi. ${ }^{19}$

Pada tahun 2015 telah dilakukan penelitian tentang kualitas hidup peserta posyandu lansia di Kecamatan Bambanglipuro. Hasilnya menunjukkan bahwa partisipasi aktif dalam kegiatan olah raga merupakan faktor paling dominan yang berhubungan dengan kualitas hidup yang lebih baik, selain faktor tidak adanya hipertensi dan status sosial ekonomi mampu. ${ }^{11}$ Namun, penelitian tersebut hanya menilai status partisipasi subjek pada program olah raga dan program lainnya di posyandu lansia yang rerata frekuensinya $1 \mathrm{kali} / \mathrm{ming}$ gu. Padahal sehari-hari lansia juga melakukan aktivitas fisik yang penting seperti kegiatan fisik atau pekerjaan sehari-hari, kegiatan rekreasional, maupun bentuk aktivitas fisik lainnya yang erat hubungannya dengan kualitas hidup, bukan hanya olahraga semata. Selain itu, penelitian tersebut juga berfokus pada peserta posyandu lansia, bukan lansia secara umum, dikarenakan tujuannya untuk menilai hubungan status partisipasi dalam kegiatan posyandu dengan kualitas hidup lansia.

Telaah pustaka menunjukkan bahwa selama ini penelitian tentang aktivitas fisik di Indonesia lebih banyak dilakukan pada remaja dan/atau dewasa muda dan hubungannya dengan penyakit metabolik dan/atau degeneratif. Penelitian tentang kualitas hidup lansia di Indonesia umumnya berhubungan dengan faktor: status tempat tinggal lansia, ${ }^{20}$ kualitas tidur, ${ }^{21}$ serta status nutrisi dan kesehatan lansia. ${ }^{22}$ Belum banyak penelitian yang berfokus tentang hubungan level aktivitas fisik dengan kualitas hidup lansia. Mengingat penting- 
nya manfaat aktivitas fisik terhadap kualitas hidup lansia maka penting untuk dilakukan studi lebih lanjut untuk memperdalam hasil penelitian sebelumnya. Oleh karena itu, penelitian ini dilakukan dengan tujuan mengetahui hubungan level aktivitas fisik dan kualitas hidup lansia di Kecamatan Bambanglipuro, Kabupaten Bantul.

\section{BAHAN DAN METODE}

Jenis penelitian ini adalah observasional analitik dengan rancangan penelitian yang digunakan adalah cross-sectional. ${ }^{23}$ Penelitian dilaksanakan di Kecamatan Bambanglipuro, Kabupaten Bantul, Yogyakarta, pada bulan Juni sampai September 2017. Populasi penelitian adalah warga lansia di Kecamatan Bambanglipuro. Sampel penelitian berjumlah 123 subjek yang terpilih melalui teknik consecutive sampling. ${ }^{23}$ Kriteria inklusi penelitian meliputi tercatat sebagai warga lansia di Kecamatan Bambanglipuro yang dibuktikan dengan Kartu Tanda Penduduk (KTP) yang sesuai dan bersedia menjadi subjek penelitian. Kriteria eksklusi penelitian, meliputi sulit atau tidak bisa berkomunikasi dengan orang lain dan/ atau mengalami penurunan fungsi kognitif (skor Kuesioner Mini Mental State Examination <24).

Variabel terikat dalam penelitian ini adalah kualitas hidup, yang terdiri dari kualitas kesehatan fisik dan kualitas kesehatan mental. Variabel bebas terdiri dari level aktivitas fisik, dengan kovariat faktor sosiodemografi (jenis kelamin, usia, dan status sosial ekonomi), serta permasalahan kesehatan yang disandang (status hipertensi dan kecacatan). Pengumpulan data dilakukan dengan wawancara terstruktur dengan kuesioner. Level aktivitas fisik subjek dalam 7 hari terakhir diukur dengan Kuesioner IPAQ-short form, yang dibedakan menjadi: tinggi ( $\geq 3000$ METs-menit/minggu), sedang (6003000 METs-menit/minggu), dan rendah $(<600$ METs-menit/minggu). ${ }^{24}$ Kualitas hidup subjek diukur dengan Kuesioner SF-36, yang dibedakan menjadi: baik (skor $\geq 50$ ) dan buruk $($ skor $<50){ }^{3}$ Kedua kuesioner tersebut telah diterjemahkan ke dalam Bahasa Indonesia dan telah lolos uji validitas dan reliabilitas dari peneliti terdahulu. Data disajikan dengan tabel, sedangkan analisis data dilakukan dengan cara deskriptif dan analitik. Hipotesis ditetapkan satu arah dengan $\alpha=0,05$ dan $\beta=$ 0,20 . Analisis bivariat dilakukan dengan uji chi square, sedangkan analisis multivariat dilakukan dengan Multiple Logistic Regression. ${ }^{25,26}$

\section{HASIL}

Karakteristik subjek disajikan pada Tabel 1 yang menunjukkan bahwa mayoritas subjek berjenis kelamin perempuan $(74,0 \%)$. Subjek lebih banyak yang berada dalam kelompok usia 60 s.d. 69 tahun $(52,8 \%)$ dan berstatus ekonomi tidak mampu $(53,7 \%)$. Mayoritas subjek menyandang hipertensi $(60,2 \%)$ dan tidak menyandang cacat $(96,7 \%)$. Berdasarkan observasi dan wawancara di lapangan, terdapat 4 subjek yang menyandang kecacatan, berupa kebutaan akibat retinopati diabetik, fraktur, serta kelemahan atau kelumpuhan ekstremitas inferior. Berdasarkan level aktivitas fisiknya dalam seminggu terakhir tampak bahwa subjek lebih banyak yang memiliki level aktivitas tinggi $(44,7 \%)$.

Gambaran tentang kualitas hidup subjek, baik kualitas kesehatan fisik maupun kualitas kesehatan mental menunjukkan mayoritas subjek memiliki kualitas hidup yang baik. Apabila dilihat lebih detail maka tampak bahwa persentase subjek yang memiliki kualitas kesehatan mental yang baik lebih tinggi daripada yang memiliki kualitas kesehatan fisik yang baik.

Untuk mengetahui hubungan masing-

Tabel 1. Karakteristik Subjek Penelitian

\begin{tabular}{lcc}
\hline \multicolumn{1}{c}{ Karakteristik } & $\mathbf{n}$ & $\mathbf{\%}$ \\
\hline Jenis Kelamin & & \\
$\quad$ Laki-laki & 32 & 26,0 \\
$\quad$ Perempuan & 91 & 74,0 \\
Kelompok Usia & & \\
$\quad 60$ s.d 69 tahun & 65 & 52,8 \\
$\quad$ 70 tahun & 58 & 47,2 \\
Status Ekonomi & & \\
$\quad$ Mampu & 57 & 46,3 \\
$\quad$ Tidak mampu & 66 & 53,7 \\
Status Hipertensi & & \\
$\quad$ Tidak hipertensi & 49 & 39,8 \\
$\quad$ Hipertensi & 74 & 60,2 \\
Status Kecacatan & & \\
$\quad$ Tidak cacat & 119 & 96,7 \\
$\quad$ Cacat & 4 & 3,3 \\
Level Aktivitas Fisik & & \\
$\quad$ Tinggi & 55 & 44,7 \\
$\quad$ Sedang & 54 & 43,9 \\
$\quad$ Rendah & 14 & 11,4 \\
\hline
\end{tabular}

Sumber: Data Primer, 2017 
Tabel 2. Hubungan Level Aktivitas Fisik dan Faktor Lainnya dengan Kualitas Kesehatan Fisik Warga Lansia

\begin{tabular}{|c|c|c|c|c|}
\hline \multirow{2}{*}{ Variabel } & \multicolumn{2}{|c|}{ Kualitas Kesehatan Fisik } & \multirow{2}{*}{ cPR $(95 \%$ CI) } & \multirow{2}{*}{$\mathbf{p}$} \\
\hline & Baik & Buruk & & \\
\hline \multicolumn{5}{|l|}{ Level aktivitas fisik } \\
\hline Tinggi & 49 & 6 & $29,94(6,47-138,63)$ & $0,000^{*}$ \\
\hline Sedang & 33 & 21 & $5,76(1,44-23,11)$ & $0,013^{*}$ \\
\hline Rendah & 3 & 11 & Ref & \\
\hline \multicolumn{5}{|l|}{ Faktor Sosio Demografi } \\
\hline \multicolumn{5}{|l|}{ Jenis Kelamin } \\
\hline Laki-laki & 22 & 10 & $0,98(0,41-2,33)$ & 0,563 \\
\hline Perempuan & 63 & 28 & & \\
\hline \multicolumn{5}{|l|}{ Kelompok Usia } \\
\hline 60 s.d 69 tahun & 55 & 10 & $5,13(2,20-11,99)$ & $0,000^{*}$ \\
\hline$\geq 70$ tahun & 30 & 28 & & \\
\hline \multicolumn{5}{|l|}{ Status Ekonomi } \\
\hline Mampu & 42 & 15 & $1,50(0,69-3,26)$ & 0,205 \\
\hline Tidak mampu & 43 & 23 & & \\
\hline \multicolumn{5}{|c|}{ Permasalahan Kesehatan yang Disandang } \\
\hline \multicolumn{5}{|c|}{ Status Hipertensi } \\
\hline Tidak hipertensi & 45 & 4 & $9,56(3,12-29,31)$ & $0,000^{*}$ \\
\hline Hipertensi & 40 & 34 & & \\
\hline \multicolumn{5}{|l|}{ Status Kecacatan } \\
\hline Tidak cacat & 84 & 35 & $7,20(0,72-71,62)$ & 0,087 \\
\hline Cacat & 1 & 3 & & \\
\hline
\end{tabular}

cPR: crude Prevalence Ratio "bermakna secara statistik

masing variabel bebas dengan variabel terikat dilakukan analisis bivariat. Rangkuman hasil analisis hubungan antara level aktivitas fisik dan faktor lainnya dengan kualitas kesehatan fisik subjek disajikan pada Tabel 2. Level aktivitas fisik tinggi (cPR $=29,94 ; 95 \% \mathrm{CI}=6,47-138,63)$ dan level aktivitas fisik sedang $(\mathrm{cPR}=5,76 ; 95 \% \mathrm{CI}=1,44-23,11)$ berhubungan dengan kualitas kesehatan fisik yang baik. Faktor lainnya yang berhubungan dengan kualitas kesehatan fisik yang baik adalah tidak adanya riwayat hipertensi $(\mathrm{cPR}=9,56 ; 95 \% \mathrm{CI}=$ 3,12-29,31) dan kelompok usia 60 s.d 69 tahun $(\mathrm{cPR}=5,13 ; 95 \% \mathrm{CI}=2,20-11,99)$.

Hasil analisis hubungan antara level aktivitas fisik dan faktor lainnya dengan kualitas kesehatan mental subjek disajikan pada Tabel 3, yang menunjukkan bahwa level aktivitas fisik tinggi $(\mathrm{cPR}=22,95 ; 95 \% \mathrm{CI}=5,15-102,20)$ dan level aktivitas fisik sedang $(\mathrm{cPR}=4,28 ; 95 \% \mathrm{CI}=$ 1,24-14,76) berhubungan dengan kualitas kesehatan mental yang baik. Faktor lainnya yang berhubungan dengan kualitas kesehatan mental yang baik adalah: tidak adanya kecacatan $(\mathrm{cPR}=10,73$;
$95 \% \mathrm{CI}=1,07-107,52)$, tidak adanya riwayat hipertensi $\quad(\mathrm{cPR}=8,31 ; \quad 95 \% \mathrm{CI}=2,35-29,33)$, serta kelompok usia 60 s.d 69 tahun $(\mathrm{cPR}=4,04$; $95 \% \mathrm{CI}=1,62-10,08)$.

Untuk mengetahui faktor yang dominan berhubungan dengan kualitas hidup ketika paparan dari variabel bebas terjadi bersama-sama di lingkungan maka dilakukan analisis multivariat. Hasil analisis terhadap faktor-faktor yang dominan berhubungan dengan kualitas kesehatan fisik disajikan pada Tabel 4 menunjukkan bahwa level aktivitas fisik tinggi (aPR=9,38; 95\% $\mathrm{CI}=1,81-48,45)$ serta tidak adanya hipertensi $(\mathrm{aPR}=5,12 ; 95 \% \mathrm{CI}=$ $1,55-16,93$ ) merupakan faktor yang paling dominan berhubungan dengan kualitas kesehatan fisik yang baik. Berdasarkan Tabel 5 tampak bahwa level aktivitas fisik tinggi $(\mathrm{aPR}=11,87 ; 95 \% \mathrm{CI}=$ $2,50-56,33)$ serta tidak adanya hipertensi $(\mathrm{aPR}=$ $4,39 ; 95 \% \mathrm{CI}=1,16-16,67)$ merupakan faktor yang dominan berhubungan dengan kualitas kesehatan mental yang baik. 
Tabel 3. Hubungan Level Aktivitas Fisik dan Faktor Lainnya dengan Kualitas Kesehatan Mental Warga Lansia

\begin{tabular}{|c|c|c|c|c|}
\hline \multirow{3}{*}{ Variabel } & \multirow{2}{*}{\multicolumn{2}{|c|}{$\begin{array}{c}\text { Kualitas Kesehatan } \\
\text { Mental }\end{array}$}} & \multirow{3}{*}{$\operatorname{cPR}(95 \% \mathrm{CI})$} & \multirow{3}{*}{$\mathbf{p}$} \\
\hline & & & & \\
\hline & Baik & Buruk & & \\
\hline \multicolumn{5}{|l|}{ Level aktivitas fisik } \\
\hline Tinggi & 51 & 4 & $22,95(5,15-102,20)$ & $0,000^{*}$ \\
\hline Sedang & 38 & 16 & $4,28(1,24-14,76)$ & $0,022^{*}$ \\
\hline Rendah & 5 & 9 & Ref & \\
\hline \multicolumn{5}{|l|}{ Faktor Sosio Demografi } \\
\hline \multicolumn{5}{|l|}{ Jenis Kelamin } \\
\hline Laki-laki & 25 & 7 & $1,14(0,43-2,99)$ & 0,500 \\
\hline Perempuan & 69 & 22 & & \\
\hline \multicolumn{5}{|l|}{ Kelompok Usia } \\
\hline 60 s.d 69 tahun & 57 & 8 & $4,04(1,62-10,08)$ & $0,002^{*}$ \\
\hline$\geq 70$ tahun & 37 & 21 & & \\
\hline \multicolumn{5}{|l|}{ Status Ekonomi } \\
\hline Mampu & 46 & 11 & $1,57(0,67-3,68)$ & 0,205 \\
\hline Tidak mampu & 48 & 18 & & \\
\hline \multicolumn{5}{|c|}{ Permasalahan Kesehatan yang Disandang } \\
\hline \multicolumn{5}{|c|}{ Status Hipertensi } \\
\hline Tidak hipertensi & 46 & 3 & $8,31(2,35-29,33)$ & $0,000^{*}$ \\
\hline Hipertensi & 48 & 26 & & \\
\hline \multicolumn{5}{|l|}{ Status Kecacatan } \\
\hline Tidak cacat & 93 & 26 & $10,73(1,07-107,52)$ & $0,040^{*}$ \\
\hline Cacat & 1 & 3 & & \\
\hline
\end{tabular}

cPR: crude Prevalence Ratio "bermakna secara statistik

Tabel 4. Hasil Analisis Multivariat Hubungan Level Aktivitas Fisik dan Faktor Lainnya dengan Kualitas Kesehatan Fisik Warga Lansia

\begin{tabular}{lcc}
\hline \multicolumn{1}{c}{ Variabel } & aPR $(\mathbf{9 5 \%} \mathbf{C I})$ & $\mathbf{p}$ \\
\hline $\begin{array}{l}\text { Kelompok Usia } \\
60 \text { s.d } 69 \text { tahun }\end{array}$ & $2,60(0,98-6,84)$ & 0,054 \\
$\geq 70$ tahun & & \\
$\begin{array}{l}\text { Status Hipertensi } \\
\quad \text { Tidak hipertensi } \\
\text { Hipertensi }\end{array}$ & $5,12(1,55-16,93)$ & $0,008^{*}$ \\
$\begin{array}{l}\text { Level Aktivitas Fisik } \\
\text { Tinggi }\end{array}$ & \\
$\quad$ Sedang & $9,38(1,81-48,45)$ & \\
Rendah & $3,21(0,76-13,61)$ & $0,008^{*}$ \\
\hline
\end{tabular}

aPR: adjusted Prevalence Ratio "bermakna secara statistik

\section{PEMBAHASAN}

Karakteristik subjek dalam penelitian ini memperkuat hasil penelitian sebelumnya yang dilakukan di Kecamatan Bambanglipuro. ${ }^{11}$ Tampak pula bahwa pada umumnya subjek memiliki level aktivitas fisik yang tinggi. Hal ini sudah cukup baik, meskipun perlu dioptimalkan lagi melalui penguatan kebijakan, sosialisasi, dan dukungan dalam pengembangan program aktivitas fisik pada lansia di wilayah tersebut. Dengan demikian, diharapkan nantinya para lansia dapat melakukan aktivitas fisik dengan lebih optimal, tanpa mengabaikan kondisi/permasalahan kesehatan yang disandangnya.

Dalam hal kualitas hidup, apabila diamati lebih lanjut tampak bahwa persentase subjek 
Tabel 5. Hasil Analisis Multivariat Hubungan Level Aktivitas Fisik dan Faktor Lainnya dengan Kualitas Kesehatan Mental Warga Lansia

\begin{tabular}{lcc}
\hline \multicolumn{1}{c}{ Variabel } & aPR $\mathbf{( 9 5 \%} \mathbf{C I})$ & $\mathbf{p}$ \\
\hline Status Hipertensi & $4,39(1,16-16,70)$ & $0,030^{*}$ \\
$\quad$ Tidak hipertensi & & \\
$\quad$ Hipertensi & & \\
Level Aktivitas Fisik & & $0,002^{*}$ \\
Tinggi & $11,87(2,50-56,33)$ & 0,084 \\
Sedang & $3,05(0,86-10,83)$ & \\
Rendah & Ref & \\
\hline
\end{tabular}

aPR: adjusted Prevalence Ratio "bermakna secara statistik

dengan kualitas kesehatan mental yang baik lebih tinggi daripada persentase subjek dengan kualitas kesehatan fisik yang baik. Hasil ini memperkuat penelitian sebelumnya yang menyatakan kondisi yang sama dengan hal tersebut. ${ }^{11}$ Meskipun demikian, dalam penelitian ini persentase lansia yang memiliki kualitas kesehatan fisik dan mental yang baik lebih rendah daripada hasil penelitian sebelumnya $(69,1 \%: 78,2 \%$ vs $76,4 \%: 81,5 \%)$. Pada penelitian sebelumnya, subjek adalah peserta posyandu lansia. Adapun pada penelitian ini subjek adalah warga lansia secara umum, baik peserta aktif, pasif, maupun bukan peserta posyandu lansia. Hal ini menunjukkan bahwa lansia peserta posyandu lansia secara umum memiliki kualitas hidup yang lebih baik.

Kualitas hidup didefinisikan sebagai persepsi individual atas posisi dalam kehidupannya dalam konteks budaya dan sistem nilai dimana mereka tinggal dan dalam hubungannya dengan tujuan, harapan, standar dan perhatian mereka. Definisi ini merupakan konsep kualitas hidup dalam arti luas. Makna yang lebih kompleks adalah persepsi individual tentang kesehatan fisik seseorang, status psikologis, derajat kemandirian, hubungan sosial, keyakinan pribadi, dan hubungan yang istimewa di masyarakat. Pada kaum lansia, kualitas hidup sangat ditentukan oleh kemampuan otonomi dan kemandirian mereka. ${ }^{2}$

Seiring bertambahnya usia yang diikuti proses menua, terjadi penurunan kemampuan fisik, mental, dan aktivitas fungsional yang terjadi pada lansia. Kaum lansia rentan mengalami penyakit yang bersifat multipatologis atau mengenai multiorgan/sistem, atipik dan non-spesifik, bersifat degeneratif, ko-patologis, serta saling terkait. Contohnya adalah penyakit hipertensi, Penyakit
Jantung Koroner (PJK), stroke, diabetes mellitus, dimensia dan osteoarthritis. Penyakit tersebut umumnya bersifat kronis progresif, cenderung menyebabkan kesakitan dan kecacatan lama yang berdampak pada kondisi kesehatan secara umum, kondisi sosial, serta keuangannya. Akibat selanjutnya adalah turunnya kualitas hidup lansia sebelum terjadinya kematian. ${ }^{8,27}$

Dengan kompleksnya permasalahan tersebut maka paradigma dalam pelayanan dan intervensi kesehatan pada lansia berubah. Semula orientasi pelayanan adalah mengurangi morbiditas dan mortalitas, serta meningkatkan usia harapan hidup, tetapi kini berkembang menjadi peningkatan kualitas hidup lansia. Dengan demikian, meskipun secara fisiologi para lansia mengalami penurunan kemampuan fisik dan biologis, tetapi tidak akan menghalangi mereka untuk tetap hidup bahagia. Pada penelitian ini, tampak bahwa mayoritas lansia memiliki kualitas hidup yang baik. Dengan demikian dapat disimpulkan bahwa kualitas hidup warga lansia di Kecamatan Bambanglipuro telah sesuai dengan konsep tersebut.

Penelitian ini menunjukkan bahwa level aktivitas fisik tinggi merupakan faktor yang paling dominan berhubungan dengan kualitas kesehatan fisik yang baik, disusul faktor tidak adanya hipertensi. Hasil ini memperkuat hasil penelitian sebelumnya yang menunjukkan bahwa partisipasi aktif dalam kegiatan olah raga $(\mathrm{aPR}=5,31$, $95 \% \mathrm{CI}=2,52-11,20)$ merupakan faktor paling dominan yang berhubungan dengan kualitas kesehatan fisik yang baik, disusul faktor tidak adanya hipertensi (aPR $=3,41,95 \% \mathrm{CI}=1,31-5,47)$ dan status ekonomi mampu $(\mathrm{aPR}=2,68,95 \% \mathrm{CI}=1,31-5,47) .{ }^{11}$ Perbedaannya adalah dalam penelitian ini status ekonomi mampu tidak termasuk dalam faktor 
yang dominan berhubungan dengan kualitas kesehatan fisik yang baik.

Aktivitas fisik (physical activity) didefinisikan sebagai semua bentuk kegiatan/pergerakan tubuh yang menyebabkan pengeluaran energi, seperti melakukan pekerjaan rumah tangga, berbelanja, berkebun, maupun berolah raga. ${ }^{28}$ Pada kelompok usia dewasa (18-64 tahun) aktivitas fisik juga mencakup kegiatan rekreasional, transportasi (bersepeda, berjalan kaki), bekerja, bermain, berolahraga atau melakukan latihan terprogram, dalam konteks sehari-hari, dan dalam kegiatan keluarga atau komunitas. ${ }^{17}$ Perbedaannya dengan istilah latihan fisik atau olah raga (physical exercise) adalah bahwa olah raga merupakan aktivitas fisik yang teratur dan terpola yang bertujuan untuk mencapai hasil berupa kesehatan atau kebugaran seperti yang diinginkan. ${ }^{28}$

Konsep aktivitas fisik yang direkomendasikan oleh WHO yang bertujuan untuk memperbaiki kesehatan kardiorespirasi dan kebugaran otot, kesehatan tulang, dan menurunkan risiko Penyakit Tidak Menular (PTM) serta depresi adalah sebagai berikut. Pertama, orang dewasa yang berusia 18-64 tahun hendaknya melakukan aktivitas fisik aerobik level sedang minimal 150 menit dalam seminggu atau melakukan setidaknya 75 menit aktivitas fisik aerobik level tinggi dalam seminggu, atau yang setara dengan kombinasi aktivitas fisik level sedangtinggi. Kedua, aktivitas aerobik hendaknya dilakukan setidaknya dalam durasi 10 menit. Ketiga, untuk menambah manfaatnya bagi kesehatan, hendaknya aktivitas fisik tersebut ditingkatkan pada aktivitas fisik aerobik level sedang menjadi 300 menit per minggu, tercapainya aktivitas fisik aerobik level tinggi 150 menit perminggu atau yang setara dengan kombinasi keduanya. Keempat, aktivitas penguatan otot hendaknya dilakukan dengan melibatkan grup-grup otot utama dalam 2 hari atau lebih perminggu. ${ }^{17}$

Penelitian ini memperkuat penelitian sebelumnya yang menunjukkan bahwa level aktivitas fisik yang tinggi pada lansia terbukti berhubungan dengan kualitas kesehatan fisik yang baik. Aktivitas fisik terbukti secara konsisten berhubungan dengan kapasitas fungsional dan kualitas hidup secara menyeluruh. ${ }^{18}$ Level aktivitas fisik yang tinggi berhubungan dengan waktu yang dihabiskan untuk duduk yang lebih rendah, cengkeraman yang lebih tinggi, rendahnya disabilitas dalam aktivitas sehari-hari, serta IMT yang lebih rendah. ${ }^{19}$ Aktivitas fisik pada lansia juga terbukti memperbaiki kapasitas fisik berupa memelihara kekuatan otot, mencegah penyakit dan mengurangi risikonya, terutama pada penyakit jantung koroner, diabetes mellitus dan stroke. ${ }^{8}$

Aktivitas fisik juga terbukti mampu menjadi "obat" bagi lansia. Level aktivitas fisik yang rendah berhubungan dengan meningkatnya risiko mortalitas dan berkembangnya gangguan kesehatan kronis pada lansia berusia di atas 65 tahun. Sebaliknya, level aktivitas fisik yang tinggi mengurangi risiko mortalitas lansia. ${ }^{28}$ Mereka yang aktif beraktivitas fisik pada level sedang 150 menit per minggu mengalami penurunan mortalitas sebesar 30\% dibandingkan mereka yang kurang aktif. Manfaat terbesar dari aktivitas fisik ini diperoleh mereka yang berusia 60 tahun ke atas. ${ }^{29}$ Oleh karena itu, tim medis mempunyai peran penting dalam mendorong pasien dan masyarakat dalam mencapai level aktivitas yang sesuai agar kesehatannya meningkat dan berumur panjang. ${ }^{28}$

Pada skala kualitas kesehatan mental, hasil penelitian ini menunjukkan bahwa level aktivitas fisik yang tinggi dan tidak adanya hipertensi merupakan faktor yang dominan berhubungan dengan kualitas kesehatan mental yang baik. Hasil ini mendukung penelitian sebelumnya yang menunjukkan bahwa status ekonomi mampu $(\mathrm{aPR}=6,38 ; 95 \% \mathrm{CI}=2,62-15,53)$, partisipasi aktif dalam kegiatan olah raga $(\mathrm{aPR}=3,97 ; 95 \% \mathrm{CI}=$ $1,83-8,64)$, serta tidak adanya hipertensi $(\mathrm{aPR}=$ $3,08 ; 95 \% \mathrm{CI}=1,39-6,82)$ merupakan faktor-faktor yang dominan berhubungan dengan kualitas kesehatan mental yang baik. ${ }^{11}$ Seperti hal-nya kualitas kesehatan fisik, perbedaan dengan penelitian ini adalah status ekonomi mampu tidak termasuk faktor yang dominan berhubungan dengan kualitas kesehatan mental.

Penelitian-penelitian sebelumnya menunjukkan subjek yang memiliki level aktivitas fisik yang tinggi berhubungan dengan kesehatan dan kualitas kesehatan mental yang baik. Terbukti bahwa skor kesepian subjek lebih rendah dan subjek lebih aktif berpartisipasi dalam kegiatan sosial, termasuk menjadi relawan. Terdapat peningkatan kemandirian, keintiman hubungan, kesehatan mental, dan vitalitas, serta kondisi psikologis yang 
lebih baik (mencegah kecemasan dan depresi, serta memperbaiki kepercayaan diri). ${ }^{7,8,18,19}$

Level aktivitas fisik yang tinggi juga berhubungan dengan kemampuan kognitif yang lebih tinggi. ${ }^{19}$ Pada orang yang tidak mengalami dimensia, aktivitas fisik yang tinggi terbukti mampu mempertahankan bahkan memperbaiki fungsi kognitifnya. Selain itu, aktif secara fisik juga terbukti mampu mengurangi terjadinya penurunan fungsi kognitif sekitar sepertiganya. Subjek yang berusia 55 tahun ke atas dengan defisit fungsi kognitif juga terbukti mengalami perbaikan kognitif setelah secara teratur melakukan aktivitas fisik pada level sedang..$^{28}$

Berdasarkan uraian tersebut dapat disimpulkan bahwa level aktivitas fisik yang tinggi berhubungan dengan kualitas hidup yang baik pada lansia, baik dalam skala kualitas kesehatan fisik maupun kualitas kesehatan mental. Oleh karena itu, perlu disusun suatu program aktivitas fisik yang sesuai pada lansia, disertai dukungan kebijakan dari pemerintah setempat dan sosialisasinya. WHO merekomendasikan kebijakan untuk mempromosikan aktivitas fisik sebagai berikut : Pertama, memastikan bahwa lingkungan fisik untuk kegiatan berjalan kaki, bersepeda, dan bentuk aktivitas fisik lainnya dapat diakses dan aman bagi semuanya. Kedua, mengenalkan kebijakan transportasi yang mempromosikan metode yang aktif dan aman dalam perjalanan menuju sekolah dan tempat kerja, seperti berjalan kaki atau bersepeda. Ketiga, memperbaiki fasilitas olah raga, rekreasi dan kegiatan rekreasional lainnya. Keempat, meningkatkan jumlah ruang yang aman yang tersedia untuk aktif bermain..$^{30,31}$

Rekomendasi dari WHO tersebut sesungguhnya dapat dijadikan panduan bagi pemerintah dalam membuat kebijakan dan mempromosikan program aktivitas fisik pada lansia. Tentu saja hal ini dengan mempertimbangkan situasi dan kondisi yang berkembang di masing-masing wilayah. Selain dapat ditujukan untuk meningkatkan kualitas hidup lansia, program tersebut juga sekaligus dapat membantu optimalisasi program pencegahan dan pengendalian PTM pada lansia.

\section{KESIMPULAN DAN SARAN}

Aktivitas fisik yang dilakukan warga lansia di Kecamatan Bambanglipuro, Kabupaten Bantul pada umumnya baik, yaitu pada level tinggi dan sedang. Mayoritas kualitas hidup warga, dalam skala kualitas kesehatan fisik maupun kualitas kesehatan mental, adalah baik. Level aktivitas fisik tinggi dan tidak adanya riwayat hipertensi terbukti berhubungan dengan kualitas hidup yang baik pada lansia. Dalam penelitian ini ditemukan data bahwa pada lansia yang memiliki permasalahan kesehatan umumnya mengalami keterbatasan aktivitas fisik. Dari telaah pustaka yang ada, menurunnya aktivitas fisik ini justru bisa semakin memperburuk kondisi kesehatan dan kualitas hidup lansia. Oleh karena itu, diperlukan penelitian lebih lanjut untuk mengetahui jenis aktivitas fisik yang paling sesuai pada lansia berdasarkan permasalahan kesehatan yang disandangnya.

\section{UCAPAN TERIMA KASIH}

Penulis menyampaikan terima kasih yang sebesar-besarnya kepada Koordinator Kopertis Wilayah V Yogyakarta beserta segenap jajarannya, yang telah memberikan dukungan pendanaaan terhadap penelitian ini melalui Hibah Bantuan Penelitian DIPA Kopertis Wilayah V Yogyakarta Tahun Anggaran 2017.

\section{DAFTAR PUSTAKA}

1. Post M. Definitions of Quality of Life: What Has Happened and How to Move On. Top Spinal Cord Inj Rehabil. 2014;20(3):167-180. DOI:10.1310/sci2003-167.

2. World Health Organization. WHOQOL: measuring quality of life. Psychol Med. 1998;28(3):551-558. DOI:10.5.12.

3. Fayers PM, Machin D. Quality of Life: Assessment, Analysis and Interpretation. 2000;7. DOI:10.1002/0470846283.

4. Presiden RI. UU RI No 36 Tentang Kesehatan. UU RI No 36 2009. 2009;1(2):1-57.

5. Motl RW, McAuley E. Physical Activity, Disability, and Quality of Life in Older Adults. Phys Med Rehabil Clin NAm. 2010;21(2):299308. DOI:10.1016/j.pmr.2009.12.006.

6. Pernambuco CS, Rodrigues BM, Bezerra JCP, et al. Quality of Life, Elderly and Physical Activity. Health (Irvine Calif). 2012;4(2):88-93. DOI:10.4236/health.2012.42014.

7. Donoghue O, Connell MO, Kenny RA. Walking to Wellbeing: Physical Activity, Social 
Participation and Psychological Health in Irish Adults Aged 50 Years and Older. Dublind; 2016.

8. World Health Organization. World Report on Ageing and Health. Geneva; 2015.

9. Masel MC, Graham JE, Reistetter TA, Markides KS, Ottenbacher KJ. Frailty and Health Related Quality of Life in Older Mexican Americans. Health Qual Life Outcomes. 2009;7. DOI:10.1186/1477-7525-7-70.

10. Pucci G, Reis RS, Rech CR, Hallal PC. Quality of Life and Physical Activity Among Adults: Population-based Study in Brazilian Adults. Qual Life Res. 2012;21(9):1537-1543. DOI:10.1007/s11136-011-0083-5.

11. Dewi SK, Kusnanto H, Pramantara IDP, Rahayujati TB. Status Partisipasi dan Kualitas Hidup Peserta Pos Pelayanan Terpadu Lanjut Usia. Kes Mas : Jurnal Kesehatan Masyarakat. 2017;11(1):28-40. DOI:http://dx.doi. org/10.12928/kes+mas.v11i1.4899.

12. Vasiljevic N, Ralevic S, Marinkovic J, et al. The Assessment of Health-Related Quality of Life in Relation to The Body Mass Index Value in The Urban Population of Belgrade. Health Qual Life Outcomes. 2008;6. DOI:10.1186/1477-7525-6-106.

13. Rana AK, Wahlin A, Lundborg CS, Kabir ZN. Impact of Health Education on Health-Related Quality of Life Among Elderly Persons: Results from a Community-Based Intervention Study in Rural Bangladesh. Health Promot Int. 2009;24(1):36-45. DOI:10.1093/heapro/ dan042.

14. Jacob ME, Abraham VJ, Abraham S, Jacob KS. The Effect of Community Based Daycare on Mental Health and Quality of Life of Elderly in Rural South India: a Community Intervention Study. Int J Geriatr Psychiatry. 2007;22(5):445-447. DOI:10.1002/gps. 1706.

15. Chiang K-J, Lu R-B, Chu H, Chang Y-C, Chou 5 K-R. Evaluation of The Effect of a Life Review Group Program on Self-Esteem and Life Satisfaction in The Elderly. Int J Geriatr Psychiatry. 2008;23:7-10. DOI:10.1002/ gps1824.

16. Idler EL, McLaughlin J, Kasl S. Religion and the Quality of Life in the Last Year of Life. Journals Gerontol - Ser B Psychol Sci Soc Sci.
2009;64(4):528-537.DOI:10.1093/geronb/ gbp028.

17. World Health Organization. Global Recommendations on Physical Activity for Health. Geneva: WHO; 2010.

18. Vagetti GC, Barbosa Filho VC, Moreira NB, Oliveira V de, Mazzardo O, Campos W de. Association Between Physical Activity and Quality of Life in The Elderly: a Systematic Review, 2000-2012. Rev Bras Psiquiatr. 2014;36(1):76-88.DOI:10.1590/1516-44462012-0895.

19. McKee G, Kearney PM, Kenny RA. The Factors Associated with Self-Reported Physical Activity in Older Adults Living in The Community. Age Ageing. 2015;44(4): 586-592. DOI:10.1093/ageing/afv042.

20. Yuliati A, Baroya N, Ririanty M. Perbedaan Kualitas Hidup Lansia yang Tinggal di Komunitas dengan di Pelayanan Sosial Lanjut Usia. J Pustaka Kesehatan. 2014;2(1): 87-94. DOI:10.1017/CBO9781107415324.004.

21. Khasanah K, Hidayati W. Kualitas Tidur Lansia Balai Rehabilitasi Sosial "MANDIRI" Semarang. J Nursing Studies. 2012;1(1):189196.

22. Nursilmi, Kusharto CM, Dwiriani CM. Hubungan Status Gizi dan Kesehatan dengan Kualitas Hidup Lansia di Dua Lokasi Berbeda. Media Kesehatan Masyarakat Indonesia. 2017;13(4):369-379.

23. Sastroasmoro S, Ismael S. Dasar-Dasar Metodologi Penelitian Klinis. Vol 4. Jakarta: CV Sagung Seto; 2011. DOI:10.1017/ CBO9781107415324.004.

24. IPAQ Research Committee. Guidelines for Data Processing and Analysis of the International Physical Activity Questionnaire (IPAQ)-Short Form. 2004; (August): 1-7. DOI:10.1016/j.ypmed.2010.07.021.

25. Dahlan MS. Statistik Untuk Kedokteran dan Kesehatan: Deskriptif, Bivariat, dan Multivariat Dilengkapi Aplikasi Menggunakan SPSS. 6th ed. Jakarta : Salemba Medika; 2014.

26. Kleinbaum D, Klein M. Logistic Regression. $2010 ; 36$.

27. Motl RW, McAuley E. Physical Activity, Disability, and Quality of Life in Older Adults. Phys Med Rehabil Clin N Am. 2010;21(2):299-308. 
DOI:10.1016/j.pmr.2009.12.006.

28. TaylorD. PhysicalActivity is Medicine for Older Adults. Postgrad Med J. 2014;90(1059):2632. DOI:10.1136/postgradmedj-2012-131366.

29. Arem H, Moore SC, Patel A, Hartge P, Freedman M, Weiderpass E. Leisure Time Physical Activity and Mortality: A Detailed Pooled Analysis of the Dose-Response Relationship. JAMA Intern Med. 2015;175(6):959-967. DOI:10.1001/jamainternmed.2015.0533. Lei- sure.

30. World Health Organisation. WHO Global Strategy on Diet, Physical Activity and Health. Geneva : World Health Organization; 2009.

31. World Health Organization. WHO Physical Activity. World Health Organization. http://www.who.int/topics/physical_activity/ en/\%0Ahttp://www.who.int/mediacentre/factsheets/fs385/en/. Published 2017. 